\author{
A.A. Dzhumabekova, A.B. Ermekova \\ Zhangir khan West Kazakhstan agrarian-technical university, Uralsk, Kazakhstan \\ (E-mail:vip.ainagul1986@mail.ru,aminaamir80@mail.ru)
}

\title{
The use of critical thinking technology at the Russian language classes
}

\begin{abstract}
This article is devoted to the problem of forming students ' critical thinking. According to the authors, this problem is often left without proper attention from the teacher. The article considers the possibility of introducing and using critical thinking technology in the educational process, and analyzes the main approaches to this definition. Special emphasis is placed on the techniques and methods that must be used at different stages of learning the Russian language, as well as specific examples of the use of these methods. The necessity of generalizing conceptual research and deepening the theoretical model of critical thinking is stated. Special attention is paid to the structure of the lesson and the techniques of this technology. The article analyzes the concept of critical thinking as a factor of professional competence, the main principles and technological phases of its development, as well as four main variants of the organization of critical thinking in students.
\end{abstract}

Keywords: critical thinking, education, problem, development, rational thinking, teacher, student.

The technology of critical thinking is one of the new educational technologies. It was proposed in the mid 90-ies of the XX century by American psychologists D. Steel, C. Meredith and C. Temple. The term «critical thinking» is understood as a system of mental characteristics and communicative qualities of a person that allow working effectively with information.

The purpose of this technology is the development of students' mental skills, which are necessary not only in studies, but also in ordinary life. The ability to make informed decisions, work with information, analyze various aspects of phenomena, and so on. This technology is aimed at the development of the student, whose main indicators are appraisal, openness to new ideas, own opinion and reflection of their own judgments. Features of this technology are:

- the educational process is based on the laws of the interaction of personality and information, the laws and mechanisms of cognition;

- at the stages of technology, various forms and strategies for working with text and the organization of discussions can be applied;

- technology strategies allow all training to be carried out on the basis of the principles of cooperation, joint planning and reflection.

To think critically is to

- Be curious;

- Use research methods;

- Ask questions to yourself;

- Reveal the causes and consequences of facts;

- Carry out a systematic search for answers;

- Doubt in the generally accepted truths;

- Develop a point of view and the ability to defend it with logical arguments;

- Attention to the opponent's arguments and their logical understanding.

A student who is able to think critically, has a variety of ways of understanding and evaluating information, can highlight contradictions, argue his point of view, relying not only on his knowledge, but also on the opinion of the interlocutor. He can carry out a systematic search for answers to questions, reveal the causes and consequences of facts.

Critical thinking does not appear on its own. To achieve any effect, it is necessary to make maximum efforts to improve and develop thinking. Each new fact is subjected to critical and rational deliberation, and the process of cognition acquires individuality and becomes productive. The desire of people for criticality and self-criticism is great, but the lack of knowledge and ability to apply this knowledge in practice can lead to criticism, i.e. wrong criticism. This problem will find its solution only with the unity of theoretical and practical research. V.I. Lenin asserted: «In order to really know an object, it is necessary to embrace, study 
all its sides, all connections and» mediations». We will never achieve this fully, but the requirement of comprehensiveness will warn us against mistakes and necrosis [2; 290].

Some features of the development and manifestations of the criticality of thinking in ontogenesis are indicated in studies on developmental psychology. In particular, they emphasize that the criticality of thinking increases with the age of students, and their self-esteem becomes more and more adequate $[1 ; 546]$. As a result, all hope is assigned to higher education institutions, where there is also the possibility of simple rash «memorization» of subjects, without forming their own point of view.

Critical thinking has 5 characteristics (D. Klester):

- Firstly, it is independent thinking;

- Secondly, this is generalized thinking;

- Thirdly, this is problematic and evaluative thinking;

- Fourth — this is reasoned thinking;

- Fifth, this is social thinking.

In the RCM program, the definition of critical thinking consists of 6 components.

Critical Thinker:

- Forms own opinion;

- Makes a deliberate choice between different opinions;

- solves problems;

- gives reason;

- Appreciates teamwork in which a common opinion emerges;

- Able to appreciate the point of view of others and recognizes that a person's perception and attitude to any issue is shaped by many factors.

The technology of critical thinking uses 3 successive stages: «challenge - comprehension of new information - reflection (reflection)».

Stage 1 - Challenge. At this phase, the knowledge available to students is updated, interest in the subject under discussion arises. To wake up a call, you can use a drawing, question, task, problem, situation, brainstorming, working with key terms, inverted logical circuits, free writing, breakdown into clusters (building a logograph — highlighting blocks of ideas), etc.

This stage has two goals: the first is the implementation of several important cognitive activities. First, the student is actively involved in the challenge of what he already knows about this topic. This forces the student to analyze their own knowledge and begin to think about the topic, which they will soon begin to understand in detail. Of great importance is the fact that through this activity the student determines the level of his own knowledge, to which new ones can be added. This very important knowledge becomes strong if it is acquired in the context of what a person already knows and understands.

The learning process is the process of linking the new with the already known one. Thus, helping students reconstruct previous knowledge and ideas can lay the broadest foundations in order to achieve a longterm understanding of new information. It also helps to illuminate misunderstandings, confusion, or errors in knowledge that never occurred if an active review of existing knowledge and beliefs had not taken place.

The second goal is the activation of the student. Learning is active, not passive activity. Too often, students sit passively in classrooms, listening to their teachers who think all the time. Whereas trainees just sit or think about something of their own. In order for students to consciously, thoroughly and critically approach the understanding of new information, they must take an active part in the learning process.

The tasks of the 1st stage are:

- independent updating of existing knowledge on the topic and the awakening of cognitive activity;

- independent determination by students of directions in the study of the topic, those aspects of it that I would like to discuss and comprehend;

- at this phase of working with information, the student determines for himself the meaning: «What does this mean for me?», «Why do I need this?».

Stage 2 - Comprehension of new information. The teacher offers students new information that they need to work out. This is the stage at where the learner meets new information. This contact may take the form of reading a text, watching a movie, listening to speeches, or performing experiments. This is also the stage of training, during which teachers have the least impact on the student. It is during this stage that the student must independently and actively participate in this work. There are teaching strategies that maintain a high level of student activity all the time. 
The main task of the stage of reflection is to maintain the activity, interest and inertia of movement created during the stage of challenge - this is the first. The second is supporting students' efforts to track their own understanding, when students track their own understanding, they relate new information to their wellestablished ideas, they consciously link the new to the already known.

Stage 3 - Reflection, Thinking. There is a comprehension of all the information obtained the 2-nd during stage.

Objectives of the reflection phase:

- to help students to independently generalize the studied material;

- to help yourself determine the direction in further study of the material

During this stage, students reinforce new knowledge and actively revise their ideas. It is at the stage that students make new knowledge their own.

At this stage, several important goals are planned. First of all, students should express new ideas and information in their own words. Students better remember what they understood in their own context, expressing it in their own words. This understanding is long-term. When a person actively reformulates understanding using his own vocabulary, he creates a personal meaningful text.

The second goal of this stage is an active exchange of ideas between students, which gives them the opportunity to expand their expressive vocabulary, as well as get acquainted with various representations. Then they can build their own ideas based on them.

The role of the teacher in the development technology of CM:

- Directs students' efforts in a certain direction;

- Encounters various judgments;

- Creates conditions encouraging the adoption of independent decisions;

- Gives students the opportunity to draw conclusions on their own;

- Prepares new cognitive situations within existing ones.

Forms and means of development of CM:

- Data collection;

- Text analysis;

- Comparison of alternative points of view;

- collective discussion;

- Different types of group and pair work;

- Debate;

- Discussions;

- Publication of students' written work.

Used techniques in the Russian language classes:

Stage 1 - Challenge

Reception «Let's dig into the memory»

1. What is the topic? (name her);

2. What do you already know about this?

3. What did you expect or feel the need to know?

4. Why do you need to know this?

The teacher announces the topic of the lesson, for example: «My small homeland.»

However, before students begin to work with literature, he suggests a little thought about a small homeland. Take a sheet of paper and a pen and within a minute answer the question: What do we call a small homeland?

It is important to write down everything that comes to mind. It does not matter if what is written down is correct or not.

After students have written down everything that they call a small homeland, it is necessary to discuss this with a partner.

After the partners have completed their discussion, group members should share their knowledge about the small homeland. As they share their knowledge, the teacher writes their ideas on a piece of paper attached to a wall or on a blackboard. Any disagreement should be tabled. He asks from time to time the question of whether everyone agrees with what is said. Discussions and friendly disagreements on the issues discussed also contribute well. 
Reception «Association»

Students are invited to read the topic of the lesson and answer the question:

- What can we talk about in the lesson?

- What association do you have when you hear the phrase: «small homeland»?

Students list all associations that have arisen. which the teacher also writes on a piece of paper or a blackboard

Reception «Confused Logical Chains»

Students integrate their own ideas with the ideas outlined in the text in order to move to a new understanding.

Correct and incorrect quotes are written on the board, students should read and put the «+» sign where they believe that the statement is correct and the «-» sign where in their opinion it is not true. For example, a quiz about the West Kazakhstan region.

Stage 2 - Reflections

The stage of reflection solves the following tasks:

- non-abstract reading of the text;

- emotional perception.

Reception «Field Marks»

Students receive the text and make notes in it:

«+» - put in the margins, if what you read corresponds to what you know;

«-» - put in the margin if what you read is contrary to what you knew or thought you knew;

$« \mathrm{~V} »-$ put in the margin if what you read is new;

«?» - put in the margin if what you read is incomprehensible or you would like to receive more detailed information on this issue.

Thus, in the process of reading the text, students make four types of marginal notes, in accordance with their knowledge and understanding. Time for work is allocated depending on the volume of text

Reception «Bloom Chamomile»

Question structure:

Type I - simple questions. They require unambiguous answers (for example: what?, where?, when?, Etc.)

Type II - clarifying questions (For example: you said something...)

Type III - practical issues (For example: How what we learned is related to life...)

Type IV - assessment questions. They require students to evaluate, compare (For example: What is your attitude to this topic)

$\mathrm{V}$ type - creative questions. They require students to show prerequisites, make a forecast (For example: What would you do if the situation developed in this way)

VI type - interpretation questions. In essence, refinement of the point of view, search for a hypothesis, transfer of knowledge to another area (For example: What opinions, in your opinion, correspond to the existing order of things)

Stage of reflection

At this stage, one, but very important task is solved:

- adjustment and systematization of knowledge.

Reception «Cluster»

I use clustering quite often both at the call stage and at the reflection stage. This is a pedagogical strategy that helps students to think freely and openly about a topic, is used to stimulate thought activity before a topic is defined or as a means to summarize, stimulate the emergence of new associations or graphic representations of new ideas. This written type of activity serves as a tool for teaching written language, gives access to one's own knowledge, understanding or ideas about a particular topic. Clustering is very simple and easy to remember:

1. You must write a keyword or sentence in the middle of the sheet or board.

2. Next, write down the words or sentences that come to mind in connection with this topic.

3. As ideas arise, connections must be established between them.

Reception «Sincwain»

Students review what they once knew, learn new things, and systematize all knowledge. The ability to summarize information, to express complex ideas, feelings and ideas in a few words is an important skill. 
It requires thoughtful reflection, based on a rich conceptual reserve. Sincwain is a poem that requires a synthesis of information and material in short terms.

Each student is given 5-7 minutes to write a sincwain. Then he will turn to his partner and they will make one of two sincwains, with which both will agree. This will give them the opportunity to talk about why they wrote it and once again critically examine this topic. In addition, this method will require that participants listen to each other and extract from the works of others those ideas that they can link with their own. Then the whole class can get acquainted with paired sincwains.

The rules for writing Sincwain:

1. In the first line, the topic is called one word (noun).

2. The second line is a description of the topic in a nutshell (two adjectives).

3. The third line is a description of the action within the topic in three verbs.

4. The fourth is a four-word phrase that shows the relationship to the topic.

5. A synonym from one word, which will repeat the essence of the topic.

Reception Essays

This type of writing assignment is used by me at the end of the lesson to help students summarize their knowledge of the topic being studied. I ask students to answer two questions:

- What did they learn about the topic?

- What would you like to know? (or ask a question to which they did not receive an answer).

The Six Hats of Critical Thinking Reception

I usually use this task at the stage of generalization and systematization, i.e. at the stage of reflection. The essence of the technique is as follows: the class is divided into six groups, each group «tries on its hat», six points of view are expressed on the same problem.

«White hat» -> ATISTIC (facts on the problem are ascertained, without discussion);

«Yellow hat» -> POSITIVE (positive points are expressed);

«Black hat» -> NEGATIVE (the group notes negative points on the problem being studied);

«Blue hat» -> ANALYTICAL (analysis is carried out, the group answers questions: why? Why? Communication?);

«Green hat» -> CREATIVE (you can express the most «crazy ideas and assumptions»);

«Red hat»-> EMOTIONAL (the group formulates their emotions that they experienced when working with the material)

Reception "Keywords»

Based on these words, make a story-guess or story-summing up of any event. The main thing is to use all keywords in the text.

Mutual Learning Reception

The easiest way to learn is by teaching others. Mutual learning occurs in groups of four to seven people. All of them are given copies of the same text. Students take turns playing the role of a teacher, a role that requires them to perform five specific actions:

1) the «teacher» summarizes the content of the paragraph;

2) he comes up with a question for the text and asks other students for it

The ability to form creative and critical thinking and teach these types of students determines the level of professional competence of the teacher. From how the teacher will be able to teach students critical thinking, provide perception, memorization, understanding, comprehension and other thought processes, the productivity of students, and, consequently, the effectiveness of the learning process itself depends [3;28].

Critical thinking is a necessary component of the professional competence of not only the teacher, who also directs students in the direction of rational thinking, but also of parents, who often completely limit the freedom of the child. Since critical thinking is social, it most often manifests itself in various discussions, disputes, and arguments of teachers and students. In such cases, students are equal participants in what is happening, and perceive the learning process not just as memorizing a scientific program, but as an exchange of experience between students and the teacher. The relations that develop between the teacher and the students «exempt the teacher from the role of a know-it-all, but make him accept the equally difficult role of the organizer of the process of cognition».

To talk about the development and formation of critical thinking of young people means talking about the development of their goal-setting to improve the quality of their rational thinking, to improve certain mental skills and abilities, and their willingness to use them in practice, whether they are studying or working. B.M. Teplov believed that criticality is the ability to strictly evaluate the work of thought, carefully 
weigh all the arguments for and against emerging hypotheses, and subject these hypotheses to comprehensive testing [4;223]. The ability to analyze and make a choice is an integral part of a developed personality, without which it will be forced to rely all the time on the opinion of authorities and experts. Therefore, the first condition for the comprehensive development of the personality is the presence of critical thinking.

\title{
References
}

1 Блонский П.П. Избранные психологические произведения / П.П. Блонский. — М.: Просвещение, 1964. -546 с.

2 Ленин В.И. Полн. собр. соч.: [В 54 т.]. — Т. 42 / В.И. Ленин. - М.: РОССПЭН, 2002. — 540 с.

3 Петрова В.Н. Педагогическое сотрудничество, или когда нравится учиться и учить / В.Н. Петрова. - М.: Сентябрь, 1999. $-128 \mathrm{c}$

4 Теплов Б.М. Психология: учеб. пос. / Б.М. Теплов. - М.: Учпедгиз, 1953. — 223 с.

\section{А.А. Джумабекова, А.Б. Ермекова}

\section{Орыс тілі сабағында сыни тұрғыдан ойлау технологиясын қолдану}

\begin{abstract}
Мақала студенттердің сыни тұрғыдан ойлауды қалыптастыру мәселесіне арналған. Авторлардың пікірінше, бұл мәселе оқытушы тарапынан көп жағдайда ескеріле бермейді. Мақалада оқу үрдісіне сыни ойлау технологиясын енгізу және қолдану мүмкіндігі қарастырылып, негізгі тәсілдері талданған. Әсіресе орыс тілін оқытудың әртүрлі сатыларында қолданылатын әдістер мен тәсілдерге ерекше көңіл бөлінген, сондай-ақ берілген тәсілдерді нақты қолдануға мысалдар келтірілген. Жалпылама тұжырымдамалық зерттеулерді жүргізу мен сыни ойлаудың теориялық модельдерін тереңдету қажеттілігі бекітілген. Осы технология бойынша сабақтың құрылымы мен әдістерін жетілдіруге ерекше назар аударылған. Сыни тұрғыдан ойлау ұғымы кәсіби құзіреттілік факторы ретінде, технологиялық фазалардың дамуы және негізгі принциптері, сонымен қатар студенттердің сыни ойлауын ұйымдастырудың төрт нұсқасы талданған.
\end{abstract}

Кілт сөздер: сыни тұрғыдан ойлау, білім, мәселе, дамыту, рационалды ойлау, оқытушы, студент.

\author{
А.А. Джумабекова, А.Б. Ермекова \\ Использование технологии критического мышления \\ на занятиях русского языка
}

\begin{abstract}
Статья посвящена проблеме формирования критического мышления студентов. По мнению авторов, это вопрос часто остается без должного внимания со стороны преподавателя. Авторами рассмотрена возможность внедрения и использования технологии критического мышления в учебном процессе, проанализированы основные подходы к данному определению. Особый акцент сделан на приемы и методы, которые необходимо использовать на разных стадиях обучения русскому языку, а также приведены конкретные примеры применения данных методов. Утверждается необходимость проведения обобщающих концептуальных исследований и углубления теоретической модели критического мышления. Особое внимание уделено структуре урока и приёмам данной технологии. Проанализированы понятие критического мышления как фактора профессиональной компетентности, основные принципы и технологические фазы его развития, а также четыре основных варианта организации критического мышления у студентов.
\end{abstract}

Ключевые слова: критическое мышление, образование, проблема, развитие, рациональное мышление, преподаватель, студент.

\section{References}

1 Blonski, P. P. (1964). Izbrannye psiholohicheskie proizvedeniia [Selected psychological works]. Moscow: Prosveshchenie [in Russian].

2 Lenin, V. I. (2002). Polnoe sobranie sochinenii [Complete works]. (Vols. 54; Vol. 42). Moscow: ROSSPEN [in Russian].

3 Petrova, V.N. (1999). Pedahohicheskoe sotrudnichestvo, ili kohda nravitsia uchitsia i uchit [Pedagogical cooperation or when you like to study and learn]. Moscow: Sentiabr [in Russian].

4 Teplov, B. M. (1953). Psiholohiia [Psychology]. Moscow: Uchpedhiz [in Russian]. 